\title{
Galectin-1 Restores Immune Tolerance to Liver Transplantation Through Activation of Hepatic Stellate Cells
}

\author{
Zhi-Jun Jiang $^{\mathrm{a}}$ Qing-Hua Shen ${ }^{\mathrm{b}} \quad$ Hai-Yong Chen $^{\mathrm{a}} \quad$ Zhe Yang $^{\mathrm{a}}$ Ming-Qi Shuai $^{\mathrm{a}}$ \\ Shu-Sen Zheng ${ }^{\text {a }}$ \\ aDepartment of Hepatobiliary and Pancreatic Surgery, the First Affiliated Hospital, Zhejiang University \\ School of Medicine, Hangzhou, 'Department of Hepatobiliary and Pancreatic Surgery, the First \\ Affiliated Hospital, Zhejiang University School of Medicine (Jinyun Branch), Jinyun, China
}

\section{Key Words}

Galectin-1 $\bullet$ Hepatic stellate cells $\cdot$ Immune tolerance $\cdot$ Liver transplantation

\begin{abstract}
Background/Aims: Immune tolerance is considered the only way to manage liver transplantation (LT). The current study hypothesized that galectin-1 via the activation of hepatic stellate cells (HSCs) is capable of inducing immune tolerance in LT. Methods: Lentiviral-mediated gene knockdown and overexpression of galectin-1 were conducted in HSC-T6 cells. Reverse transcription quantitative polymerase chain reaction and western blot analysis were used to determine galectin-1 expression. LT was performed in $20 \mathrm{C} 57 \mathrm{BL} / \mathrm{J} 6$ mice and $20 \mathrm{C} 3 \mathrm{H}$ mice. T-cells were assigned into control, Galectin-1 shRNA, Galectin-1 OE, Galectin-1 OE SB431542, Galectin-1 OE Sulforaphane, Galectin-1 OE Y27632, and Galectin-1 OE UO126 groups. CFSE, flow cytometry, and ELISA were respectively employed to detect T-cell proliferation, $\mathrm{CD}^{+}$/ $\mathrm{CD} 8^{+}$ratio and IL-2, IL-10 and TGF- $\beta$ levels. After establishing mouse models of immune tolerance and acute rejection, immunohistochemistry, TUNEL, and immunofluorescence assay were performed to determine $\mathrm{CD}^{+}$expression, apoptosis, $\alpha-S M A$, and desmin. Mouse models of $\mathrm{CCl}_{4}$-induced liver fibrosis were established, followed by assigning the control and $\mathrm{CCl} 4$ groups. ELISA was used to determine ALT, AST, TBIL and Hyp levels. A total of 3 $\mathrm{C} 57 \mathrm{BL} / \mathrm{J} 6$ mice (donor) and $6 \mathrm{C} 3 \mathrm{H}$ mice (recipient) were grouped into the control and $\mathrm{UO} 126$ groups, followed by ELISA detection for IL-2, IL-10 and TGF- $\beta$. Results: In T-cells, galectin- 1 shRNA increased cell proliferation and IL-2 levels with reduced IL-10 and TGF- $\beta$ levels, while the Galectin-1 OE and Galectin-1 OE UO126 groups revealed the opposite results. Galectin-1 overexpression elevated the ratio of the $\mathrm{CD}^{+}$to $\mathrm{CD} 8^{+} \mathrm{T}$-cells. The acute rejection group exhibited enhanced desmin expression and reduced $\alpha$-SMA expression. Compared with the immune tolerance group, the acute rejection group displayed higher galectin-1 expression, a positive expression rate of $\mathrm{CD}^{+} \mathrm{T}$-cells, and an increased apoptosis rate. Compared with the control $_{1}$ group, the $\mathrm{CCl} 4$ group exhibited higher galectin- 1 expression, ALT, AST, TBIL, and Hyp
\end{abstract}


Jiang et al.: Galectin-1 Induces Immune Tolerance in LT Via Hscs

levels, $\alpha$-SMA expression and $\mathrm{CD}^{+} / \mathrm{CD}^{+} \mathrm{T}$-cell ratio, in addition to decreased expression of desmin. Compared with the control ${ }_{2}$ group, UO126 increased galectin- 1 expressions, IL-10 and TGF- $\beta$ levels and reduced IL-2 levels with inactivated HSCs. Conclusions: The findings of the current study indicated that the overexpression of galectin-1 promoted the activation of HSCs, which reduced the inflammatory response by exerting immunosuppressive effects and accordingly contributed to immune tolerance in LT.

\section{Introduction}

(C) 2018 The Author(s)

Published by S. Karger AG, Basel

Liver transplantation (LT) is regarded as the ideal treatment for acute and chronic end-stage liver diseases and early hepatocellular carcinoma; however, the side effects of immunosuppression, transplantation of functionally impaired grafts and recurrence of original disease cannot be ignored over the long term [1]. Additionally, the preparative regimens are important for treatment of the indicated disease and for prevention of graft rejection [2]. It was previously reported that acute rejection following LT must be overcome to achieve better prognoses in liver transplant recipients [3]. Similarly, another study investigated the balance between the regulatory mechanisms of the induction of immune tolerance and the pathogenic factors associated with immune effects involving rejection to overcome acute rejection following LT [4]. Recently, spontaneous immune tolerance in LT of mice has attracted the attention of various researchers in transplantation-immunity studies [5]. Moreover, non-parenchymal liver cells, including Kupffer cells (KCs) and hepatic stellate cells (HSCs), have been demonstrated to contribute to the tolerogenic properties of the liver, suggesting that they play potential roles in immune tolerance [6]. In line with the aforementioned data, it was reported that multiple mechanisms are involved in immune tolerance via induction of HSCs, such as attenuation of effector T lymphocyte functions and augmentation of regulatory T lymphocytes [7]. Interestingly, galectin-1 has been reported to negatively mediate the activation and survival of T-cells in human tumors and to regulate immune tolerance in the spleen and thymus via apoptosis by binding to CD45 ${ }^{+} \mathrm{T}$-cells [8, 9]. Furthermore, a study revealed that HSCs serve as important immune regulators in LT by inducing T-cells [10], the prolonged depletion of which after LT leads to life-threatening infections [11]. Thus, the current study speculated that galectin- 1 might influence immune tolerance in LT by regulating HSCs.

Galectin-1 belongs to a family of B-galactoside binding proteins and is widely expressed in a variety of normal and pathological tissues and organs, such as the thymus, liver, and smooth muscles $[4,12]$. Furthermore, galectin-1 is known to play significant roles in multiple biological processes, including inflammatory response, tumorigenesis, and immune cell homeostasis [9]. In addition, galectin-1 has been reported to be involved in transplantation tolerance due to its effects on the reduction of morbidity and mortality [13]. Moreover, the upregulation of galectin- 1 has been suggested to enhance apoptosis of T-cells and cytokine production induced by HSCs [14]. HSCs, as fat-storing cells, store approximately $80 \%$ of the body's vitamin A in lipid droplets, [15] and as antigen-presenting cells (APCs), which are involved in hepatic fibrosis [16]. Furthermore, it has been previously demonstrated that co-transplanted HSCs exert effects on islet allografts protecting them from rejection and alleviating the severity of graft-versus-host disease, suggesting that HSCs possess immunosuppressive functions [17]. In addition, a previous study revealed that activated HSCs combined with B7-H1 suppressed T-cell responses via mediation of T-cell apoptosis [18]. Therefore, the current study aimed to explore the molecular mechanisms of galectin-1 in immune tolerance to LT by regulating HSCs. 


\section{Cellular Physiology Cell Physiol Biochem 2018;48:863-879

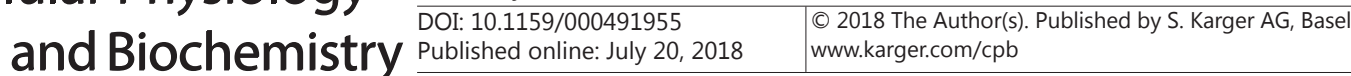

Jiang et al.: Galectin-1 Induces Immune Tolerance in LT Via Hscs

\section{Materials and Methods}

\section{Experimental animals}

First, the mouse HSC line HSC-T6 (0089, Shanghai Fuxiang Biotech Co., Ltd., Shanghai, China) was cultured in Iscoves modified Dulbecco medium (IMDM, LM-I1092/500, Shanghai Biosun Sci \& Tech Co., Ltd., Shanghai, China) containing $10 \%$ fetal bovine serum (FBS) at $37^{\circ} \mathrm{C}$ with $5 \% \mathrm{CO}_{2}$ in air. The cell line was subcultured once every 2-3 days. A total of $20 \mathrm{C} 3 \mathrm{H} / \mathrm{HeJ}$ male mice (aged: 3-5 weeks; Jinan Biobase Biotech Co., Ltd., Jinan, Shandong, China), and 20 C57BL/J6 male mice (aged: 7-8 weeks old; Beijing HFK Bioscience Co., Ltd., Beijing, China) were raised in separate cages according to their types (C3H or C57BL/J6 mice). All of the mice were housed under controlled conditions of temperature $\left(18-22^{\circ} \mathrm{C}\right)$, relative humidity $(40-70 \%)$, and noise levels $<50 \mathrm{~dB}$ and with ad libitum access to food and water, in addition to a 12-h light/dark cycle.

\section{Construction of lentiviral vectors}

A total of 3 short hairpin RNAs (shRNAs) were designed and synthesized with galectin-1 as the target with cleavage sites of Bgl II and Hind III on both sides and a 9-nt hairpin structure. The nonsense shRNA sequence was regarded as the negative control (NC) group. The expression of galectin-1 in the Galectin-1sh1, Galectin-1-sh2, and Galectin-1-sh3 groups was observed. The sequences are shown in Table 1 [19]. Next, $1 \mu \mathrm{l}$ of single-stranded shRNA ( $3 \mu \mathrm{g} / \mu \mathrm{l})$ was added to $48 \mu \mathrm{l}$ of annealing buffer $(100 \mathrm{mmol} / \mathrm{l} \mathrm{NaCl}$ and $50 \mathrm{mmol} / \mathrm{l} \mathrm{N}$-2-hydroxyethylpiperazine-N'-2-ethanesulfonic acid [HEPES], pH 7.4), followed by immersion in a water bath at $95^{\circ} \mathrm{C}$ for $4 \mathrm{~min}, 70^{\circ} \mathrm{C}$ for $10 \mathrm{~min}, 37^{\circ} \mathrm{C}$ for $20 \mathrm{~min}$, and $10^{\circ} \mathrm{C}$ for $10 \mathrm{~min}$ and then preservation at $4^{\circ} \mathrm{C}$ for further use. Simultaneously, a lentiviral vector with galectin- 1 OE was constructed. Then, the lentivirus vector plasmid PNL-IRES 2 -EGFP was co-transfected using helper plasmids in 293T-cells. The lentivirus plasmid pLVshRNA-eGFP (VL3101, Invogen Tech. Co., Ltd., Beijing, China) system was adopted to transfect 293T-cells. The collected lentivirus was centrifuged at 50, $000 \mathrm{~g}$ for $2 \mathrm{~h}$ at $4^{\circ} \mathrm{C}$, and the supernatant was discarded. The condensed lentivirus was collected and preserved at $4^{\circ} \mathrm{C}$ for further use. After $24 \mathrm{~h}$, the culture medium in the wells was replaced with $500 \mu \mathrm{l}$ of fresh medium and added to $5 \mu \mathrm{g} / \mathrm{ml}$ polybrene (0832-050, Shanghai Sidansai Biotechnology Co, Ltd., Shanghai, China), followed by incubation for 8 h. A total of 3 wells were set to determine lentiviral titers as follows: the $1^{\text {st }}$ well had $25 \mu$ l of lentivirus added, the $2^{\text {nd }}$ had $250 \mu \mathrm{l}$ of lentiviral particles added, and the $3^{\text {rd }}$ had polybrene in the same concentration added. The culture medium was replaced with $1 \mathrm{ml}$ of fresh culture medium without polybrene within $12 \mathrm{~h}$, followed by further incubation for 24-48 h. Next, the HSC-T6 cells were infected with the condensed lentivirus another time. Puromycxin (60210ES25, Shanghai YEASEN Biotechnology Co., Ltd., Shanghai, China) was employed to screen for positive transfection of HSC-T6 cells. After $72 \mathrm{~h}$ of culture, the shRNA exhibiting better interference effects was selected by reverse transcription quantitative polymerase chain reaction (RT-qPCR) for subsequent experiments, when $90 \%$ transfection efficiency was verified using a fluorescence microscope.

\section{$R T-q P C R$}

RT-qPCR was performed to determine expression of galectin-1 in each group, and the group of cells exhibiting the best interfering effect was selected for subsequent experiments. HSC-T6 cells in logarithmic growth phase were added to $1 \mathrm{ml}$ of TRIzol ${ }^{\circledR}$ reagent (Invitrogen Inc., Carlsbad, CA, USA). Next, the total RNA content in the cells was extracted according to the manufacturer's protocol for TRIzol ${ }^{\circledR}$ Reagent. The purity and concentration of RNA were measured using ultraviolet (UV) spectrophotometry (UV1901, Shanghai Aucy Technology Instrument Co., Ltd., Shanghai, China). RNA (A260/A280) ranging from 1.8 to 2.0 was adjusted to a concentration of $50 \mathrm{ng} / \mu \mathrm{l}$ and was used as a template for reverse transcription reaction using the PrimeScript ${ }^{\mathrm{TM}}$ RT Reagent Kit (RR047A, Takara, Beijing Think-Far Technology Co., Ltd., Beijing, China). The reaction conditions were as follows: denaturation at $65^{\circ} \mathrm{C}$ for $10 \mathrm{~min}$, annealing at $25^{\circ} \mathrm{C}$ for $10 \mathrm{~min}$, extension at $37^{\circ} \mathrm{C}$ for 60 min, and $70^{\circ} \mathrm{C}$ for $10 \mathrm{~min}$. The collected cDNA $(50 \mathrm{ng} / \mu \mathrm{l})$ was preserved at $-80^{\circ} \mathrm{C}$ for further use. The primers (Table 2) were designed using Gene Tool software and were synthesized
Table 1. ShRNA sequences with Galectin-1 as the target gene. Note: ShRNA, short hairpin RNA

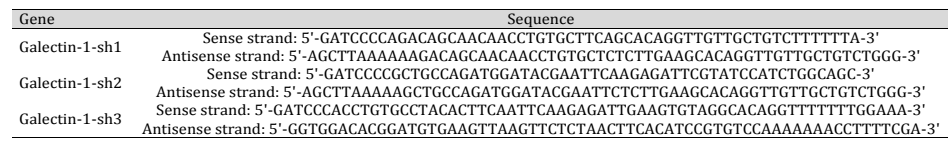




\section{Cellular Physiology Cell Physiol Biochem 2018;48:863-879

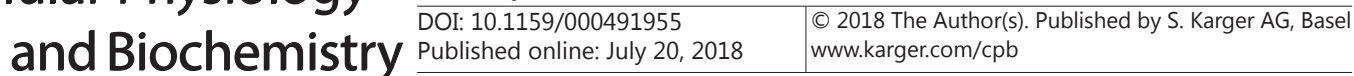

Jiang et al.: Galectin-1 Induces Immune Tolerance in LT Via Hscs

by Beijing TsingKe Biological Technology Co., Ltd. (Beijing, China) [20]. Subsequently, RT-qPCR was performed with the ABI PRISM ${ }^{\circledR} 7900$ HT apparatus using the two-step method ,with glyceraldehyde-3-phosphate dehydrogenase (GAPDH) serving as the internal reference. The reaction conditions were as follows: pre-denaturation at $95^{\circ} \mathrm{C}$ for $30 \mathrm{~s}$, followed by 40 cycles of denaturation at $95^{\circ} \mathrm{C}$ for $5 \mathrm{~s}$ and annealing at $58^{\circ} \mathrm{C}$ for $30 \mathrm{~s}$. The relative mRNA expression of galectin- 1 was calculated using the $2^{-\Delta \Delta \mathrm{ct}}$ method. Triplicate parallel wells were set for each target gene of each sample. The experiment was conducted three times.
Table 2. Primer sequence for reverse transcription quantitative polymerase chain reaction. Note: GAPDH, glyceraldehyde-3-phosphate dehydrogenase

\begin{tabular}{lc}
\hline Gene & Primer sequence \\
\hline \multirow{2}{*}{ Galectin-1 } & $\begin{array}{c}\text { Forward: 5'-GCATCACAGAGGT-3' } \\
\text { Reverse: 5'-AGGCCACGCACTTAATCTTG-3' }\end{array}$ \\
GAPDH & Forward: 5'-TGCACCACCAACTGCTTAGC-3' \\
& Reverse: 5'-GGCATGGACTGTGGTCATGAG-3' \\
\hline
\end{tabular}

\section{Western blot analysis}

HSC-T6 cells in logarithmic growth phase were centrifuged at $3000 \mathrm{r} / \mathrm{min}$ at $4^{\circ} \mathrm{C}$ for $20 \mathrm{~min}$, and the supernatant was discarded. After packed cell volume (PCV, condensed cell volume after centrifugation) was estimated, per $20 \mu \mathrm{l}$ of PCV cells were lysed with $100 \mu \mathrm{L}$ of lysate and $1 \mu \mathrm{l}$ of phosphatase inhibitor (Roche, Beijing Jiamay Biotechnology Co., Ltd., Beijing, China) on ice for $30 \mathrm{~min}$ and were centrifuged at 12000 $\mathrm{r} / \mathrm{min}$ at low temperature for $10 \mathrm{~min}$. The protein samples (50 $\mu \mathrm{g}$ in each group) were dissolved in $2 \times$ sodium dodecyl sulphate (SDS) sample buffer and boiled for $5 \mathrm{~min}$ for degeneration. Next, the proteins were separated using 10\% SDS-polyacrylamide gel electrophoresis (SDS-PAGE) and then were transferred to a poly-vinylidene fluoride (PVDF) membrane and blocked with 5\% skimmed milk at room temperature for $1 \mathrm{~h}$. After rinsing with phosphate-buffered saline (PBS) for $2 \mathrm{~min}$, the membrane was incubated overnight at $4{ }^{\circ} \mathrm{C}$ with diluted rabbit anti-mouse primary antibody of galectin-1 (dilution ratio of 1: 1000, ab58085, Abcam, London, UK) and then rinsed with Tris-buffered saline Tween-20 (TBST) three times. Later, the samples were cultured with the secondary antibody of horseradish peroxidase (HPR)-labeled goat antirabbit immunoglobulin G (IgG) (dilution ratio of 1:5000) for $1 \mathrm{~h}$, followed by rinsing with TBST for $3 \times 5 \mathrm{~min}$. Next, the protein samples were developed using an enhanced chemiluminescence (ECL) kit (10001, Beijing Keyushenlan Technology Co., Ltd., Beijing, China), exposed to X-rays. A gel imaging analysis system (GelDoc $\mathrm{XR}^{+}$, Bio-Rad Laboratories, Hercules, CA, USA) was employed to analyze the absorbance values of the bands. The average absorbance ratio of the target protein band to the internal reference band was regarded as the relative protein expression. The experiment was conducted three times.

\section{T-cell isolation}

$\mathrm{C} 3 \mathrm{H}$ mice were anesthetized with $2 \%$ sodium pentobarbital, fixed in the supine position on operating tables, and sterilized. The skin overlying the abdomen was incised along the linea alba to expose the abdominal cavity and spleen. Then, a 5-ml syringe was used for multiple pricking into the collected spleen. After spleen samples were rinsed with PBS, the samples were centrifuged, and the supernatant was removed. Next, the samples were lysed by erythrocyte lysate and centrifuged, and the supernatant was discarded. The cell samples were re-suspended in Dulbecco's minimum essential medium (DMEM) medium (SH30022, Beijing North TZ-Biotech Develop, Co. Ltd., Beijing, China) containing 10\% FBS and were incubated for 3 h. Subsequently, the suspended cells were extracted. T-cells were isolated from the cell suspension using a Nylon wool column, labeled with carboxyfluorescein diacetate succinimidyl ester (CFSE, $5 \mu \mathrm{mol} / \mathrm{L}, \mathrm{C} 375$, Dojindo China Co., Ltd., Shanghai, China), and incubated while avoiding exposure to light at $37^{\circ} \mathrm{C}$ for $10 \mathrm{~min}$. The centrifuge tube was shaken gently at two min intervals for uniform CFSE labeling. Then, the samples were centrifuged at $3000 \mathrm{r} / \mathrm{min}$ for $5 \mathrm{~min}$ to remove the remnant CFSE.

\section{Cell grouping and culture}

HSC-T6 cells in logarithmic growth phase were randomly divided into the control group (normal HSC-T6 cell line), the Galectin-1 shRNA group (HSC-T6 cell line with galectin-1 shRNA), the Galectin-1 OE group (HSC-T6 cell line with galectin-1 overexpression), the Galectin-1 OE SB431542 group (HSC-T6 cell line with galectin-1 overexpression cultured with transforming growth factor beta (TGF- $\beta$ )/Smads inhibitor), the Galectin-1 OE Sulforaphane group (HSC-T6 cell line with galectin-1 overexpression cultured with phosphoinositide 3-kinase (PI3K)/Akt inhibitor), the Galectin-1 OE Y27632 group (HSC-T6 cell line with galectin-1 overexpression cultured with Rho/Rho-associated protein kinase (ROCK) inhibitor), and 


\section{Cellular Physiology Cell Physiol Biochem 2018;48:863-879 \begin{tabular}{c|c|c|c|} 
DOI: 10.1159/000491955 & $\begin{array}{l}\text { O 2018 The Author(s). Published by S. Karger AG, Basel } \\
\text { www.karger.com/cpb }\end{array}$
\end{tabular}}

Jiang et al.: Galectin-1 Induces Immune Tolerance in LT Via Hscs

the Galectin-1 OE U0126 group (HSC-T6 cell line with galectin-1 overexpression cultured with mitogenactivated protein kinase/extracellular signal-regulated kinase (MAPK/ERK) inhibitor). The HSC-T6 cells in the control, Galectin-1 shRNA, and Galectin-1 OE groups were cultured with T-cells, while the HSC-T6 cells with galectin-1 overexpression in the Galectin-1 OE SB431542, Galectin-1 OE Sulforaphane, Galectin-1 OE Y27632, and Galectin-1 OE U0126 groups were cultured with T-cells in vitro and $10 \mu \mathrm{mol} / \mathrm{L}$ signaling pathway inhibitors (according to the grouping, TGF- $\beta$ /Smads inhibitor SB431542, PI3K/Akt inhibitor sulforaphane, Rho/ROCK inhibitor Y27632, MAPK/ERK inhibitor U0126) for $3 \mathrm{~h}$ in 96-well plates. CFSE labeled T-cells were suspended at a density of $1 \times 10^{7}$ cells $/ \mathrm{ml}$ using DMEM complete medium. Triplicate parallel wells were set for each group. Then, T-cells were seeded in wells (at a density of $2 \times 10^{5}$ cells/well) and were subcultured in an incubator at $37^{\circ} \mathrm{C}$ with $5 \% \mathrm{CO}_{2}$ in air.

\section{CFSE staining and flow cytometry detecting T lymphocyte proliferation}

At days 3, 5, and 7 after culture, the T-cells labeled with CFSE in each group were selected and allowed to attain room temperature. The CellTrace ${ }^{\mathrm{TM}}$ CFSE Proliferation Kit (KGA318, Shanghai Yuanxiang Medical Instrument Co., Ltd., Shanghai, China) was employed to detect the proliferation of T-cells according to the kit instructions. Flow cytometry (Becton Dickinson Bio-sciences, San Jose, CA, USA) was used to detect the splitpeak, and Modfit software was used to calculate the number of cells split per passage and the proliferation rate of T lymphocytes. The experiment was conducted three times.

\section{Flow cytometry detecting the ratio of $C D 4^{+}$to $C D 8^{+}$T-cells}

At days 3,5, and 7 after culturing, the T-cells labeled with CFSE in each group were selected and added to PBS (pH 7.2, $0.01 \mathrm{~mol} / \mathrm{L}$ ) to a total volume of $1 \mathrm{ml}$. Glacial acetic acid at a concentration of $2 \%$ was used for cell counting. Next, the cells were cultured with fluorescein isothiocyanate/phyco-erythrina (FITC/PE)conjugated rat anti-mouse $\mathrm{CD}^{+} / \mathrm{CD}^{+}$monoclonal antibody (SZB0003, dilution ratio of 1:100, Shanghai Boyao Biotech Co., Ltd., Shanghai, China) at $4^{\circ} \mathrm{C}$ for $50 \mathrm{~min}$. Then, the cells were rinsed with PBS two times (pH 7.2, $0.01 \mathrm{~mol} / \mathrm{L})$, and immune parameters were detected using FACScan flow cytometry. Splenocytes were collected using CellQuest software, and the ratio of $\mathrm{CD} 4^{+}$to $\mathrm{CD}^{+} \mathrm{T}$-cells was analyzed by ModFit software. The experiment was conducted three times.

\section{Enzyme-linked immunosorbent assay (ELISA)}

At days 3, 5, and 7 after culture, T-cells in each group were selected and digested with pancreatin. After centrifugation at $1500 \mathrm{r} / \mathrm{min}$ for $10 \mathrm{~min}$, the T-cells were diluted with serum-free medium to a density of $10^{6}$ cells $/ \mathrm{ml}$ and were accordingly counted. The diluted cell suspension was added to a 96-well plate (100 $\mu \mathrm{l}$ of suspension for each well) and was cultured at $37^{\circ} \mathrm{C}$ overnight for cell adherence. The following day, the levels of IL-2, IL-10, and TGF- $\beta$ were detected with ELISA kits purchased form Wuhan Moshake Biological Technology Co., Ltd. (Wuhan, Hubei, China). The samples and the ELISA kits for IL-2 (kit No: 69-99852), IL10 (kit No: 69-99847), and TGF- $\beta$ (kit No: 69-50020) were placed outside for 30 min prior to the experiment and allowed to reach room temperature. A microplate reader (Multiskan GO, Thermo Fisher Scientific, CA, USA) was employed to analyze the optical density (OD) value. The procedures were in accordance with respective kit instructions. The experiment was conducted three times.

\section{Establishment of mouse models of immune tolerance and acute rejection in allogeneic $L T$}

A total of $4 \mathrm{C} 57 \mathrm{BL} / \mathrm{J} 6$ mice (donor) and $6 \mathrm{C} 3 \mathrm{H}$ mice (receptor) were randomly selected and assigned to the sham operation group (2 C3H mice), the immune tolerance group ( $1 \mathrm{C} 57 \mathrm{BL} / \mathrm{J} 6$ mouse and $2 \mathrm{C} 3 \mathrm{H}$ mice) and the acute rejection group ( $1 \mathrm{C} 57 \mathrm{BL} / \mathrm{J} 6$ mouse and $2 \mathrm{C} 3 \mathrm{H}$ mice). The donor mice received pretreatment with Flt3L (bs-5905R, Beijing Boosen Biotechnology Co., Ltd., Beijing, China). At day 7 before LT, the donor mice were administered intraperitoneal injections of $10 \mu \mathrm{g}$ of Flt3L dissolved in $100 \mu \mathrm{l}$ of normal saline once per day for seven days. Then, $10 \mathrm{~d}$ after the operation, no mouse deaths were observed, indicating that the establishment of models was successful. Subsequently, the mice were anesthetized with $2 \%$ sodium pentobarbital via intraperitoneal injection and fixed in the prone position. The skin overlying the abdomen was incised to collect liver tissues. One part of the tissue was stored in liquid nitrogen. The other part was fixed in $10 \%$ neutral buffered formalin for $24 \mathrm{~h}$, dehydrated with graded ethanol, and embedded in paraffin. 


\section{Cellular Physiology Cell Physiol Biochem 2018;48:863-879 \begin{tabular}{ll|l} 
and Biochemistry & $\begin{array}{l}\text { DOI: 10.1159/000491955 } \\
\text { Published online: July 20, } 2018\end{array}$ & $\begin{array}{l}\text { @ } 2018 \text { The Author(s). Published by S. Karger AG, Basel } \\
\text { www.karger.com/cpb }\end{array}$ \\
\hline
\end{tabular}}

Jiang et al.: Galectin-1 Induces Immune Tolerance in LT Via Hscs

\section{Hematoxylin-eosin staining}

Paraffin-embedded specimens were sliced into $5 \mu \mathrm{m}$ serial sections, followed by extension at $45^{\circ} \mathrm{C}$ and drying for $1 \mathrm{~h}$ at $60^{\circ} \mathrm{C}$. After dewaxing by xylene I and xylene II for $5 \mathrm{~min}$ respectively, liver samples were dehydrated with graded ethanol at 100\%, 95\%, 80\%, and 70\% (each for $2 \mathrm{~min}$ ), rinsed with distilled water for $2 \times 5 \mathrm{~min}$, and hydrated. Then, the samples were stained using hematoxylin-eosin (Beijing Solarbio Science \& Technology Co., Ltd., Beijing, China) for $3 \mathrm{~min}$, followed by rinsing under running water for $5 \mathrm{~min}$. Subsequently, the samples were dehydrated with $70 \%$ ethanol for $5 \mathrm{~min}$ and $80 \%$ ethanol for $5 \mathrm{~min}$, cleaned with xylene I and xylene II for $5 \mathrm{~min}$, and then sealed with neutral gum with cover glass. The inflammatory cell infiltration and damage to liver cells in the transplanted liver in the sham operation, immune tolerance, and acute rejection groups were observed under a light microscope (XP-330, Shanghai, Bingyu Optical Instrument Co., Ltd., Shanghai, China).

\section{Immunohistochemistry}

Paraffin-embedded sections were immersed in $3 \% \mathrm{H}_{2} \mathrm{O}_{2}$, dewaxed with xylene I and xylene II for 10 min, respectively, and dehydrated with graded ethanol at $100 \%, 95 \%, 80 \%$, and $70 \%$ (each for 2 min). Next, the sections were rinsed with distilled water for $2 \times 5$ min on a shaking table. After immersion in $3 \% \mathrm{H}_{2} \mathrm{O}_{2}$ for $10 \mathrm{~min}$, the sections were rinsed with distilled water, followed by antigen repair at high pressure for $50 \mathrm{~s}$. Next, the sections were allowed to cool to room temperature and rinsed with PBS, blocked with 5\% bovine serum albumin (BSA), incubated at $37^{\circ} \mathrm{C}$ for $30 \mathrm{~min}$, and then incubated with rabbit anti-mouse $\mathrm{CD}^{+}$ primary antibody (ab16669, dilution ratio of 1:400, Abcam, London, UK) at $4^{\circ} \mathrm{C}$ overnight. Subsequently, the sections were incubated with goat anti-rabbit IgG-HRP secondary antibody (SE134, Beijing Solarbio Science \& Technology Co., Ltd., Beijing, China) at $37^{\circ} \mathrm{C}$ for $30 \mathrm{~min}$, reacted with streptavidin-biotin (SAB) working fluid, stained with diaminobenzidine (DAB), and counterstained by hematoxylin for 5 min, followed by rinsing under running water for $10 \mathrm{~min}$, dehydration, transparency, sealing, and microscopy. PBS was used to replace the primary antibody as the NC. The criteria for immunohistochemistry staining results [20] were as follows: the percentage of cells in positive expression was more than $10 \%$, and cells with brownish yellow membranes, cytoplasm and vascular endothelium were regarded as CD3+-positive cells. A total of 5 fields under a high-power lens were randomly selected to detect the position of positive expression and the positive expression of $\mathrm{CD}^{+}$. Pathology images and a character report management system (HPIAS 1000) were adopted to detect the mean OD value of positive cells. The experiment was repeated three times.

Terminal deoxynucleotidyl transferase-mediated dUTP-biotin nick end-labeling (TUNEL) assay

Paraffin-embedded sections were dewaxed with xylene I and xylene II for $10 \mathrm{~min}$, respectively, followed by immersion in ethanol at 100\%, 95\%, 80\%, and 70\% (each for $2 \mathrm{~min}$ ) and rinsing with PBS for $3 \times 5 \mathrm{~min}$. Next, the sections were incubated with proteinase $\mathrm{K}$ at $37^{\circ} \mathrm{C}$ for $30 \mathrm{~min}$, rinsed with PBS for $3 \times 5 \mathrm{~min}$, fixed in paraformaldehyde for $2 \mathrm{~h}$, and rinsed with PBS for $3 \times 5 \mathrm{~min}$. Subsequently, the sections were blocked with methanol containing $3 \% \mathrm{H}_{2} \mathrm{O}_{2}$ for $10 \mathrm{~min}$, rinsed with PBS for $3 \times 5 \mathrm{~min}$, and then immersed in $20 \%$ sucrose phosphate buffer at $4^{\circ} \mathrm{C}$ overnight. The following day, the specimens were sliced into $20 \mu \mathrm{m}$ serial sections using a cutting machine at $-22^{\circ} \mathrm{C}$. A total of 10 sections from each mouse were stained using TUNEL assay, and the TUNEL kit was purchased from Boehringer Mannheim Company (Germany). Cells with dark particles, observed under a light microscope (Leica DM4 P, Shanghai Meijing Electronic Co., Ltd., Shanghai, China), were regarded as apoptotic cells. In addition, 10 fields under high power lens sections in each group were randomly selected to determine the apoptotic nuclei, total number of cells, and apoptotic index (AI = apoptotic cells/total cells). The experiment was conducted three times.

\section{Immunofluorescence assay}

The levels of $\alpha$-smooth muscle actin ( $\alpha$-SMA), as a marker of HSCs in the activation phase, and desmin, as a marker of HSCs in the resting phase, were detected using immunofluorescent double staining to detect the activation of HSCs in mouse models. The frozen liver tissues were embedded with an embedding agent, sliced into $5 \mu \mathrm{m}$ sections with a freezing microtome, and dried overnight. Next, the sections were fixed in cold acetone for $10 \mathrm{~min}$ and rinsed with PBS for $3 \times 5 \mathrm{~min}$. After being permeated with $0.2 \%$ Triton X-100, the sections were rinsed with PBS for $3 \times 5 \mathrm{~min}$, fixed with goat serum for $30 \mathrm{~min}$ at room temperature, followed by rinsing with PBS for $3 \times 5 \mathrm{~min}$, and then incubated with FITC-labeled rabbit anti-mouse antibodies of 


\section{Cellular Physiology Cell Physiol Biochem 2018;48:863-879 \begin{tabular}{l|l} 
DOI: 10.1159/000491955 & $\begin{array}{l}\text { O 2018 The Author(s). Published by S. Karger AG, Basel } \\
\text { www.karger.com/cpb }\end{array}$
\end{tabular}}

Jiang et al.: Galectin-1 Induces Immune Tolerance in LT Via Hscs

$\alpha$-SMA (dilution ratio of 1:500, ab5831, Abcam, London, UK) and desmin (dilution ratio of 1:500, ab15200, Abcam, London, UK) at $4^{\circ} \mathrm{C}$ overnight. After rinsing with PBS for $3 \times 5 \mathrm{~min}$, the sections were washed with distilled water to remove residual PBS, mounted in glycerol and observed under a fluorescence microscope.

\section{Establishment of mouse models of CCl4-induced liver fibrosis}

A total of $6 \mathrm{C} 57 \mathrm{BL} / \mathrm{J} 6$ mice were randomly assigned into the control ${ }_{1}$ group and the $\mathrm{CCl} 4$ group with three mice in each group. The mice were acclimated to the surrounding conditions of $22^{\circ} \mathrm{C}$ in temperature, $55 \%$ humidity, and ample food and water in a 12 -h light/dark cycle. $\mathrm{CCl}_{4}(20 \mathrm{ml})$ was mixed with olive oil (30 $\mathrm{ml}$ ) and stirred with a magnetic stirrer for 8-12 h. Next, a mixture of $\mathrm{CCl}_{4} /$ olive oil with $40 \%$ volume fraction was prepared. Mice were administered intraperitoneal injections of prepared $2 \mathrm{ml} / \mathrm{kg} \mathrm{CCl}_{4} /$ olive oil (namely, $0.8 \mathrm{ml} / \mathrm{kg} \mathrm{CCl} 4$ ) two times per week to establish mouse models of liver fibrosis. Mice in the control group were injected with equal amounts of olive oil. There were no deaths during model establishment. Six weeks after injection, normal mice were observed to be responsive with normal eating and drinking, as well as normal weights. The mice in the $\mathrm{CCl}_{4}$ group were found to be overweight, unresponsive, and presented with rough fur. Failed mouse models were removed, while all of the mouse models were established successfully. After 6 weeks, the mice were administered intraperitoneal injections of $2 \%$ sodium pentobarbital for deep anesthesia. Then, whole blood in eyeballs $(0.4-0.6 \mathrm{ml})$ from each mouse was extracted and preserved in serum tubes. Next, the skin overlying the abdomen was incised immediately. Liver tissues (100 mg) from the left lobe were collected, placed in frozen tubes, and preserved in liquid nitrogen for further use. The remnant liver from the left lobe was collected and fixed in $10 \%$ neutral formalin buffer for $12-24 \mathrm{~h}$. Next, the samples were embedded in paraffin and sliced into sections for further experimentation.

Masson staining of liver lobule tissues in the control $_{1}$ and $\mathrm{CCl}_{4}$ groups

Paraffin-embedded sections were immersed in $3 \% \mathrm{H}_{2} \mathrm{O}_{2}$, dewaxed with xylene I and xylene II (each for $10 \mathrm{~min}$ ), and dehydrated in graded ethanol at $100 \%, 95 \%, 80 \%$, and $70 \%$ (each for $2 \mathrm{~min}$ ). Next, the sections were rinsed with distilled water for $2 \times 5 \mathrm{~min}$ on a shaking table and stained with hematoxylin-eosin (Beijing Solarbio Science \& Technology Co., Ltd., Beijing, China) for $15 \mathrm{~min}$. After being rinsed with $1 \%$ acetic acid for $10 \mathrm{~min}$, the sample sections were reacted with phospho molybdate and aniline blue (each for $10 \mathrm{~min}$ ) and rinsed with $1 \%$ acetic acid, followed by dehydration with ethanol and clearing with xylene. Next, the samples were mounted in neutral gum, and liver fibrosis in liver lobules in the control ${ }_{1}$ and $\mathrm{CCl}_{4}$ groups was observed under a light microscope (XP-330, Shanghai, Bingyu Optical Instrument Co., Ltd., Shanghai, China).

\section{Mouse groupings}

A total of $3 \mathrm{C} 57 \mathrm{BL} / \mathrm{J} 6$ mice (donor) and $6 \mathrm{C} 3 \mathrm{H}$ mice (receptor) were randomly selected to conduct further grouping. The $\mathrm{C} 3 \mathrm{H}$ mice were randomly classified into the control ${ }_{2}$ group and the U0126 group, with three mice in each group. In addition, $\mathrm{C} 3 \mathrm{H}$ mice were used to establish mouse models of immune tolerance. At days 2, 4, and 6 after the operation, the $\mathrm{C} 3 \mathrm{H}$ mice were injected with a MAPK signaling pathway inhibitor, U0126. After $10 \mathrm{~d}$, the $\mathrm{C} 3 \mathrm{H}$ mice were administered a $10 \%$ intraperitoneal injection of $2 \%$ sodium pentobarbital. Blood from the eyeballs of the mice was extracted once the mice were appropriately anesthetized. The whole blood (0.4-0.6 ml) of each mouse was preserved and placed in serum tubes. Next, the skin overlying the abdomen of mice was incised immediately. The liver tissues (each group $100 \mathrm{mg}$ ) were extracted, placed in frozen tubes, and preserved for further use in liquid nitrogen. The remnant tissues were collected and fixed in 10\% neutral formalin buffer for $12-24 \mathrm{~h}$. Next, the samples were embedded in paraffin and sliced into sections for the following experiments.

\section{Statistical analysis}

Statistical analyses were performed using SPSS software, version 21.0 (IBM Corp Armonk, NY, USA). Measurement data are expressed as the mean \pm standard deviation (SD). Comparisons between two groups were performed using the $t$-test, and comparisons among multiple groups were analyzed by one-way analysis of variance (ANOVA). A level of $p<0.05$ was considered to be statistically significant. 


\section{Cellular Physiology Cell Physiol Biochem 2018;48:863-879 \begin{tabular}{ll|l} 
and Biochemistry Published online: July 20, 2018 & $\begin{array}{l}\text { C } 2018 \text { The Author(s). Published by S. Karger AG, Basel } \\
\text { www.karger.com/cpb }\end{array}$
\end{tabular}}

Jiang et al.: Galectin-1 Induces Immune Tolerance in LT Via Hscs

\section{Results}

Galectin-1 expression is decreased in the Galectin-1-sh groups and increased in the Galectin-1 OE group

First, the results of western blot analysis (Fig. 1A-B) revealed that, compared with the NC group, the expression of galectin-1 was found to be decreased in the other groups $(p<$ 0.05). Among the Galectin-1-sh1, Galectin-1-sh2, and Galectin-1-sh3 groups, the expression of galectin-1 in the Galectin-1-sh3 group was the lowest, indicating that the Galectin-1-sh3 group exhibited the best interference effect. Therefore, cells in the Galectin-1-sh3 group were selected for the following experiments.

Additionally, the results of western blot analysis are shown in Fig. 1C-D. It was observed that the protein expression of galectin-1 was much higher in the Galectin-1 OE group, compared to the NC group $(p<0.05)$.

Changes of T-cell proliferation rate, percentage of CD4+ and CD8+ cells and expression levels of $I L-2, I L-10$ and TGF- $\beta$

Next, CFSE, flow cytometry and ELISA were employed to determine the T-cell proliferation rate, percentage of CD4+ and CD8+ cells and expression levels of IL-2, IL-10 and TGF- $\beta$, respectively. The outcomes of CFSE and flow cytometry are shown in Fig. $2 \mathrm{~A}$. The results revealed that the proliferation rate of T-cells in the Galectin-1 OE U0126 group was the lowest among the seven groups. Compared with the control group, the proliferation rate of T-cells was found to be increased in the Galectin-1 shRNA group, whereas reduced rates were observed in the Galectin-1 OE and Galectin-1 OE U0126 groups $(p<0.05)$. There were no significant differences in the proliferation rate of T-cells among the control, Galectin-1 OE SB431542, Galectin-1 OE Sulforaphane, and Galectin-1 OE Y27632 groups (all $p>0.05$ ).

The results of flow cytometry shown in Fig. $2 \mathrm{~B}$ indicated that, since the $3^{\text {rd }}$ day, compared with the control group, the ratio of $\mathrm{CD}^{+}$to $\mathrm{CD}^{+} \mathrm{T}$-cells was found to be obviously elevated in the Galectin-1 OE group but notably decreased in the Galectin-1 shRNA, Galectin-1 OE SB431542, Galectin-1 OE Sulforaphane, Galectin-1 OE Y27632, and Galectin-1 OE U0126 groups (all $p<0.05$ ). Compared to the Galectin-1 OE group, the ratio of $\mathrm{CD} 4^{+}$to $\mathrm{CD} 8^{+} \mathrm{T}$-cells was significantly reduced in the Galectin-1 OE SB431542, Galectin-1 OE Sulforaphane, Galectin-1 OE Y27632, and Galectin-1 OE U0126 groups (all $p<0.05$ ). The results suggested that overexpression of galectin- 1 enhanced the percentage of $\mathrm{CD} 4^{+} \mathrm{T}$-cells but decreased the percentage of $\mathrm{CD}^{+}$T-cells, exerting an immunosuppressive effect. In addition, the immunosuppressive effect could be enhanced by the addition of U0126, an inhibitor of the MAPK/ERK signaling pathway.

Fig. 1. Galectin-1 expression is decreased in the Galectin-1-sh groups and increased in the Galectin-1 OE group. Panels A and B, western blot analysis showed that the Galectin-1-sh3 group exhibited lower Galectin-1 protein levels, compared to the other two groups; Panels C and D, western blot analysis suggested that the Galectin-1 OE group had higher Galectin-1 protein levels than the NC group; NC, negative control; GAPDH, glyceraldehyde-3-phosphate dehydrogenase; *, p<0.05, vs. the NC group; \#, p<0.05, vs. the Galectin-1-sh1 and Galectin-1-sh2 groups. The t-test was used for the comparison between the two groups, while oneway analysis of variance (ANOVA) was used for the comparison among groups. The experiment was

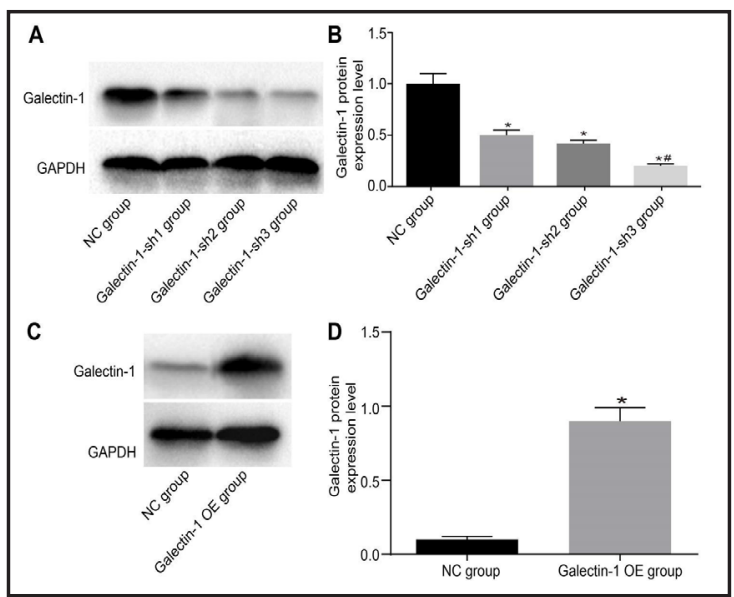
performed in triplicate, and the result was three times the mean \pm standard deviation. 
Fig. 2. Changes in T-cell proliferation rate, percentages of CD4+ and CD8+ cells and expression levels of IL-2, IL-10 and TGF- $\beta$. Panel A, CFSE together with flow cytometry outcomes showed that T-cell proliferation rate was higher in the Galectin-1 shRNA group; Panel B, results of flow cytometry showed that Galectin-1 overexpression enhanced the percentage of $\mathrm{CD}^{+}$ T-cells but decreased the percentage of $\mathrm{CD}^{+} \mathrm{T}$-cells, which exerted immunosuppressive effects, while the immunosuppressive effect could be enhanced by addition of U0126, an inhibitor of the MAPK/

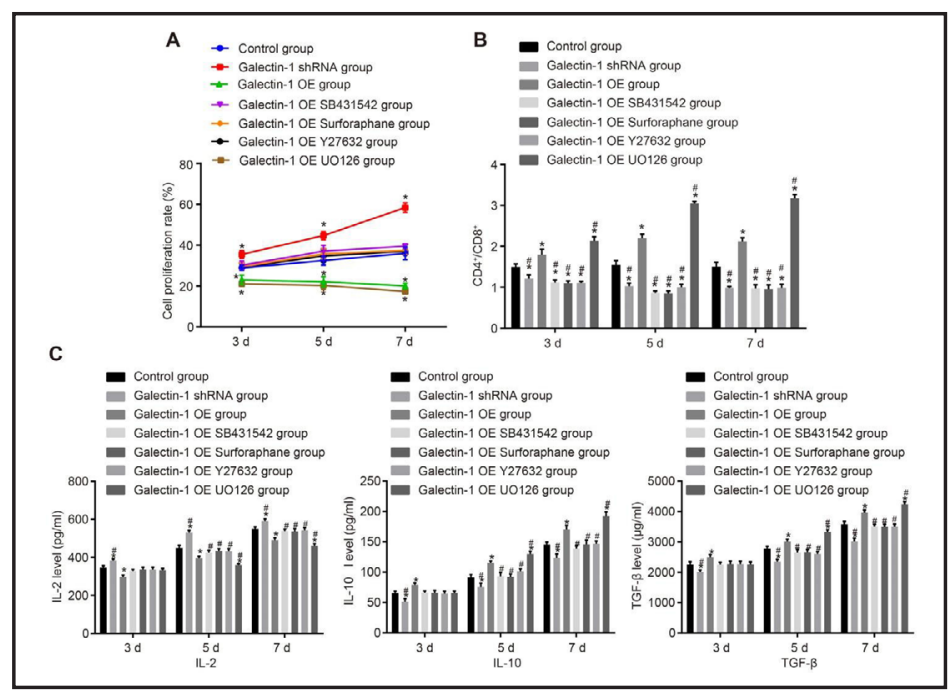
ERK signaling pathway; Panel C, the findings of ELISA showed that Galectin-1 overexpression inhibited IL-2 levels but promoted the levels of IL-10 and TGF- $\beta$, which suppressed inflammatory responses. However, the immunosuppressive effect can be enhanced by the addition of U0126, an inhibitor of the MAPK/ERK signaling pathway; ${ }^{*}, \mathrm{p}<0.05$, vs. the NC group; \#, p<0.05, vs. the Galectin-1 OE group. One-way analysis of variance (ANOVA) was used for the comparison among groups. The experiment was performed in triplicate, and the result was three times the mean \pm standard deviation. NC, negative control; GAPDH, glyceraldehyde-3-phosphate dehydrogenase; shRNA, short hairpin RNA; CFSE, carboxyfluorescein diacetate succinimidyl ester; IL-2, interleukin-2; IL-10, interleukin-10; TGF- $\beta$, transforming growth factor beta.

ELISA results (Fig. 2C) showed that, since the $3^{\text {rd }}$ day, compared with the control group, the IL-2 level was found to be remarkably elevated, and the levels of IL-10 and TGF- $\beta$ were notably decreased in the Galectin-1 shRNA group, while the opposite trends were observed in the Galectin-1 OE group (all $p<0.05$ ). Since the $5^{\text {th }}$ day, compared with the control group, the Galectin-1 OE U0126 group showed decreased IL-2 levels and increased levels of IL-10 and TGF- $\beta$ (all $p<0.05$ ). Compared with the Galectin-1 OE group, IL-2 levels were found to be significantly elevated, and the levels of IL-10 and TGF- $\beta$ were decreased in the Galectin-1 OE SB431542, Galectin-1 OE Sulforaphane, and Galectin-1 OE Y27632 groups, while the opposite trends were observed in the Galectin-1 OE U0126 group (all $p<0.05$ ). The results suggested that overexpression of galectin- 1 inhibited IL- 2 levels but increased the levels of IL-10 and TGF- $\beta$, which suppressed inflammatory responses. In addition, the immunosuppressive effect could be enhanced by the addition of UO126, an inhibitor of the MAPK/ERK signaling pathway.

Histopathological changes, positive expression rate of CD3+, HSCs apoptosis, galectin-1 protein expression and the activation of HSCs in the sham operation and immune tolerance, acute rejection groups

Next, HE staining, immunohistochemistry, TUNEL assay, western blot analysis and immunofluorescence assay were performed to conduct histopathological examination, evaluation of $\mathrm{CD}^{+}$positive rate, $\mathrm{HSC}$ apoptosis, galectin-1 protein expression and activation of HSCs, respectively. The results of HE staining (Fig. 3A) indicated that the sham operation group showed no evident inflammatory cell infiltration or cell necrosis. The immune tolerance group presented with local proliferation with inflammatory cell infiltration, cell necrosis, and congestion. Further, the acute rejection group showed obvious inflammatory cell infiltration and congestion, in addition to more cell necrosis.

The results of immunohistochemistry (Fig. 3B) showed that, $10 \mathrm{~d}$ after model establishment, the positive expression rate of $\mathrm{CD}^{+}$was much higher in the immune 


\section{Cellular Physiology and Biochemistry}

Fig. 3. Observation of histopathological changes, positive expression rate of $\mathrm{CD} 3+$, HSC apoptosis, Galectin-1 protein expression and the activation of HSCs in the sham operation and immune tolerance, acute rejection groups. Panel A, the immune tolerance group presented local proliferation with inflammatory cell infiltration, cell necrosis, and congestion evaluated by HE staining $(\times 200)$; scale $=50$ $\mu \mathrm{m}$; Panel $\mathrm{B}$, the positive expression rate of $\mathrm{CD}^{+}$was higher in the acute rejection group than in the immune tolerance group by immunohistochemistry ( $x$ 200); scale $=50 \mu \mathrm{m}$; Panel $\mathrm{C}$, the hepatocyte apoptotic index in the immune tolerance group was decreased compared to that in the acute rejection group but still relatively serious by TUNEL staining ( $\times 100)$; scale $=100 \mu \mathrm{m}$; Panel $\mathrm{D}$, the protein expression of Galectin-1 increased in the immune tolerance group but showed a more significant increase in the acute rejection group by western blot analysis; Panel E, HSCs were massively activated in the acute rejection group by im-

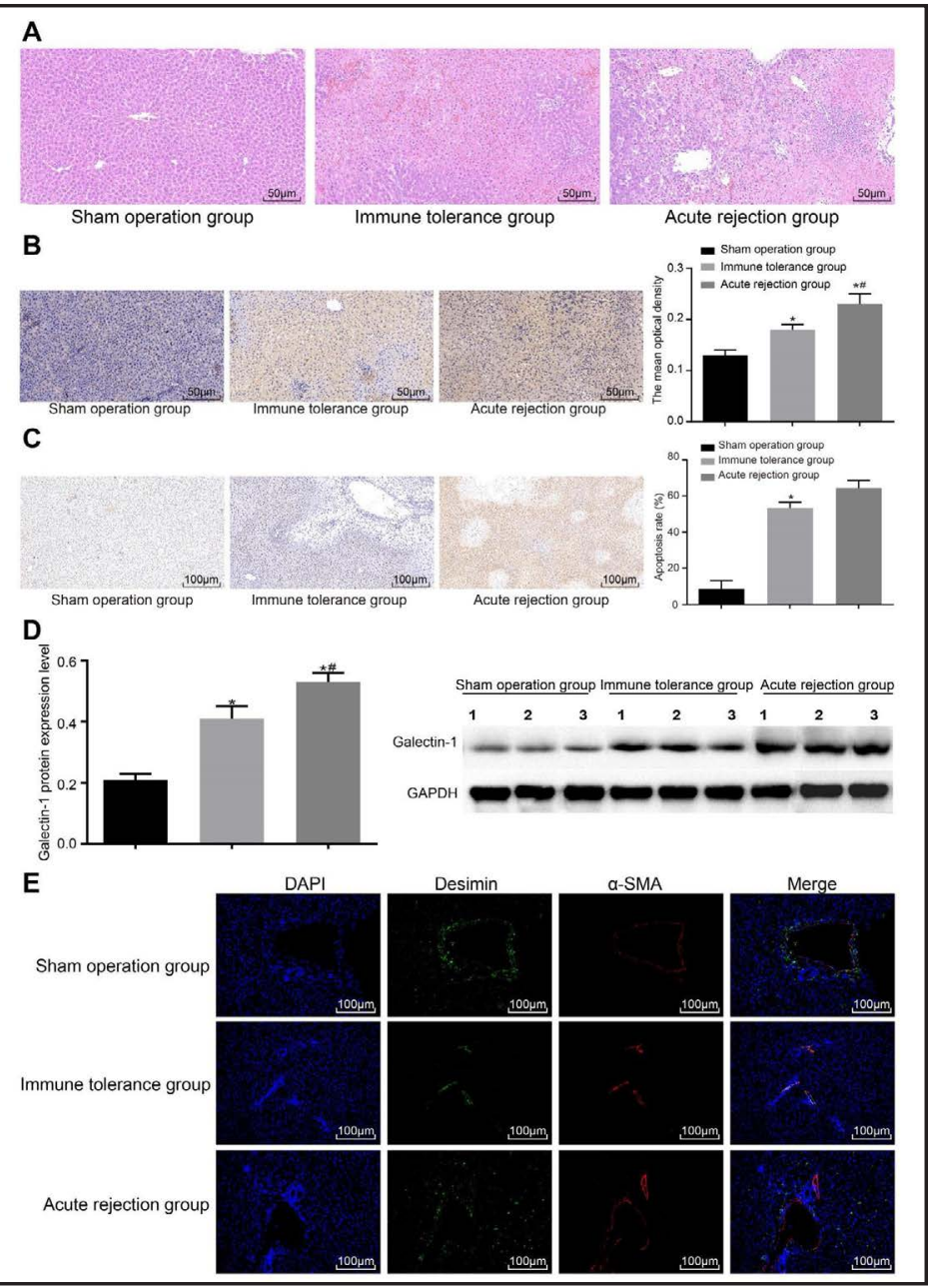
munofluorescence assay ( $\times 200)$;

scale $=50 \mu \mathrm{m} ;{ }^{*}, \mathrm{p}<0.05$, vs. the sham operation group; \#, $<<0.05$, vs. the immune tolerance group. One-way analysis of variance (ANOVA) was used for the comparison among groups. The experiment was carried out in triplicate, and the result was three times the mean \pm standard deviation. HE, hematoxylin-eosin; TUNEL, terminal deoxynucleotidyl transferase-mediated dUTP-biotin nick end-labeling; GAPDH, glyceraldehyde3-phosphate dehydrogenase; DAPI, 4', 6-diamidino-2-phenylindole; $\alpha$-SMA, $\alpha$-smooth muscle actin; HSC, hepatic stellate cell.

tolerance and acute rejection groups, compared to the sham operation group (all $p<0.05$ ). In the acute rejection group, the positive expression rate of $\mathrm{CD}^{+}$was found to be higher than in the immune tolerance group $(p<0.05)$.

The TUNEL assay results (Fig. 3C) showed that the apoptotic index was found to be evidently elevated in the immune tolerance and acute rejection groups, compared to the sham group (all $p<0.05$ ). The apoptotic index showed an evident increase in the acute rejection group, compared to the immune tolerance group (all $p<0.05$ ). The results indicated that allotransplantation of the liver led to hepatocyte apoptosis, and the hepatocyte apoptotic index in the immune tolerance group was decreased compared to the acute rejection group but still relatively serious.

The results of western blot analysis (Fig. 3D) indicated that, compared with the sham operation group, the protein expression of galectin-1 was found to be increased in the immune tolerance group, but it showed a more significant increase in the acute rejection group (all $p<0.05$ ).

\section{KARGER}




\section{Cellular Physiology Cell Physiol Biochem 2018;48:863-879 \begin{tabular}{l|l} 
DOI: 10.1159/000491955 & O 2018 The Author(s). Published by S. Karger AG, Basel \\
www.karger.com/cpb
\end{tabular} Jiang et al.: Galectin-1 Induces Immune Tolerance in LT Via Hscs}

The results of immunofluorescence assay (Fig. 3E) indicated that, compared with the sham operation group, desmin levels in the immune tolerance group significantly decreased with elevated levels of $\alpha$-SMA, while the acute rejection group exhibited the opposite results. Compared with the immune tolerance group, the level of desmin in the acute rejection group was found to be notably increased with reduced levels of $\alpha$-SMA. The results revealed that HSCs were in a stationary state at the normal stage. When the HSCs underwent injuries, the HSCs were activated, and the phenotype of the HSCs changed from the stationary type to the activated type. In addition, HSCs in the immune tolerance group were found to be significantly activated.

Histopathological changes of liver lobule tissues, changes of liver fibrosis, levels of ALT, AST, TBIL, and Hyp, and protein expression of galectin-1 in the control and CCl4 groups

Subsequently, HE staining, Masson staining, ELISA, western blot analysis and immunofluorescence assay were employed to measure histopathological changes of liver lobule tissues, changes in liver fibrosis, levels of ALT, AST, TBIL, and Hyp, protein expression of galectin- 1 and activation of HSCs. HE staining results (Fig. 4A) indicated that the control group showed no obvious inflammatory cell infiltration or cell necrosis, in addition to clear liver lobule structures. The CCl4 group presented local proliferation with inflammatory cell infiltration, cell necrosis, and congestion in some parts.

Fig. 4. Observation of histopathological changes of liver lobule tissues, changes of liver fibrosis, levels of ALT, AST, TBIL, and Hyp, and protein expression of Galectin-1 in the control and $\mathrm{CCl}_{1}$ groups. Panel $\mathrm{A}$, the $\mathrm{CCl} 4$ group presented local proliferation with inflammatory cell infiltration, cell necrosis, and congestion in some parts observed by HE staining $(\times 200)$, scale = $50 \mu \mathrm{m}$; Panel B, liver fibrosis evidently increased in the CCl4 group detected by Masson staining ( $x$ 200), scale $=50 \mu \mathrm{m}$; Panel C, CCl4 increased levels of ALT, AST, TBIL and Hyp, and liver damage was serious in the $\mathrm{CCl} 4$ group by ELISA, $\mathrm{n}=3$; Panel $\mathrm{D}$, protein expression of Galectin-1 was increased in $\mathrm{CCl} 4$ group by western blot analysis; Panel E, the level of desmin in the $\mathrm{CCl} 4$ group significantly decreased with elevated levels of $\alpha$-SMA, evaluated by immunofluorescence assay $(\times 200)$, scale $=50 \mu \mathrm{m} .{ }^{*}$, $\mathrm{p}<0.05$, vs. the control ${ }_{1}$ group; HE, hematoxylin-eosin; ALT, alanine aminotransferase; AST, aspartate aminotransferase; TBIL, total bilirubin; Hyp, hydroxyproline; GAPDH, glyceraldehyde-3-phosphate dehydrogenase; DAPI, 4', 6-diamidino-2-phenylindole; $\alpha$-SMA, $\alpha$-smooth muscle actin; HSC, hepatic stellate cell.

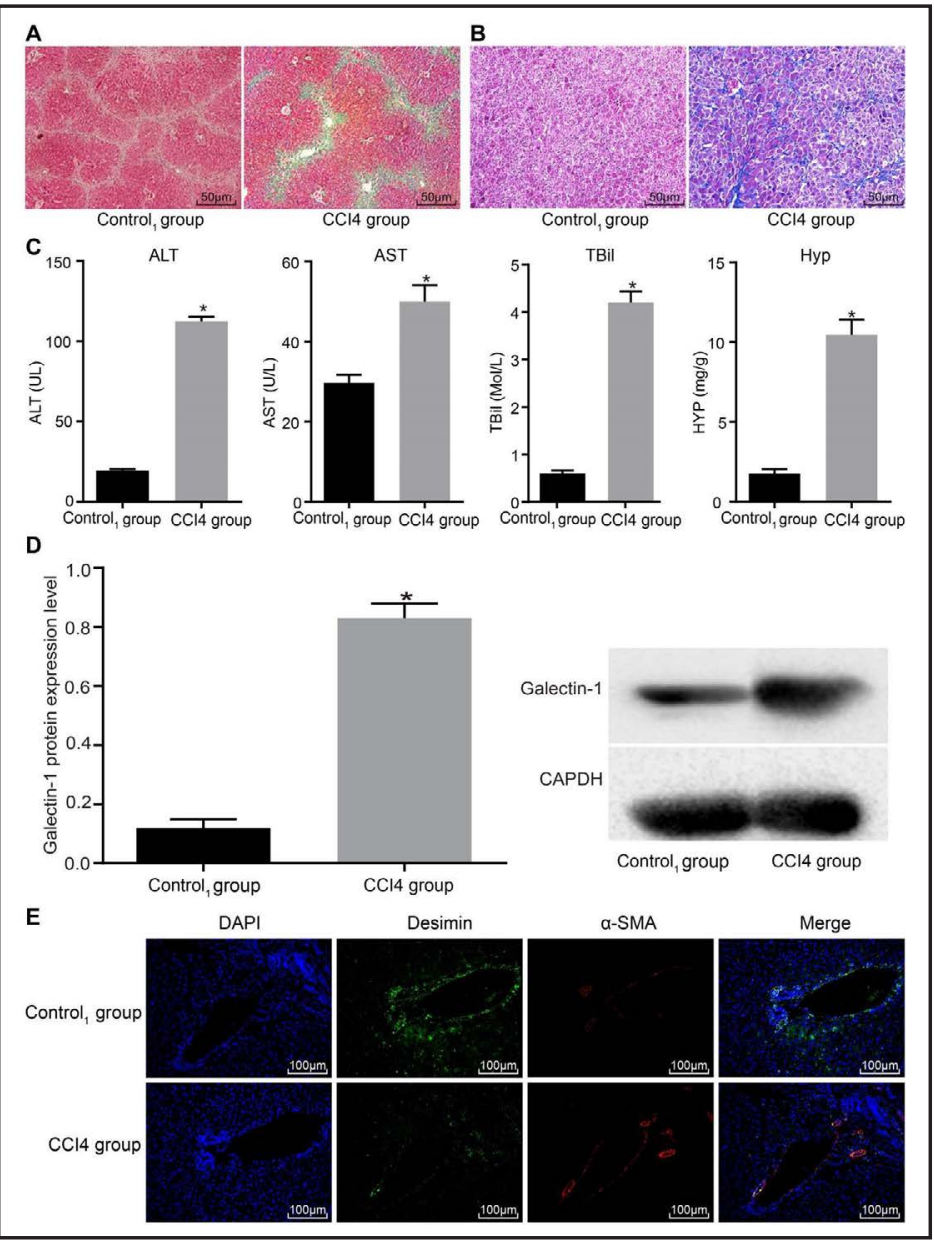




\section{Cellular Physiology Cell Physiol Biochem 2018;48:863-879

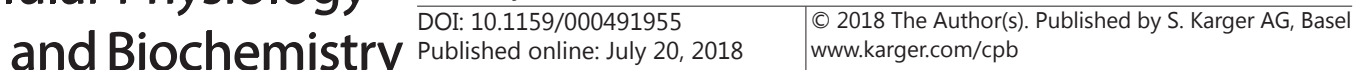 Jiang et al.: Galectin-1 Induces Immune Tolerance in LT Via Hscs}

Masson staining results (Fig. 4B) indicated that the liver tissues were normal, and liver fibrosis was decreased in the control ${ }_{1}$ group, while liver fibrosis was found to be evidently increased in the $\mathrm{CCl}_{4}$ group.

The ELISA results (Fig. 4C) showed that levels of ALT, AST, TBIL, and Hyp were found to be notably elevated in the $\mathrm{CCl}_{4}$ group compared to the control ${ }_{1}$ group (all $p<0.05$ ), indicating that there was serious liver damage in the $\mathrm{CCl}_{4}$ group.

The results of western blot analysis (Fig. 4D) showed that protein expression of galectin- 1 was found to be notably elevated in the $\mathrm{CCl}_{4}$ group compared to the control group (all $p<0.05$ ).

The results of immunofluorescence assay (Fig. 4E) indicated that, compared with the control ${ }_{1}$ group, the level of desmin in the $\mathrm{CCl}_{4}$ group was found to be significantly decreased, in addition to having elevated $\alpha$-SMA. At the normal stage, the HSCs were observed to be in the stationary state. When HSCs underwent injury, the HSCs were activated, and subsequently, the phenotype of HSCs changed from the stationary type to the activated type.

Immune tolerance of liver transplantation, histopathological changes of liver lobule tissues, expression levels of IL-2, IL-10 and TGF- $\beta$, percentage of CD4+ and CD8+cells, and protein expression of galectin-1

In the following experiments, immunofluorescence staining, HE staining, ELISA, flow cytometry and western blot analysis were employed to measure the immune tolerance of liver transplantation, histopathological changes of liver lobule tissues, expression levels of IL2 , IL-10 and TGF- $\beta$, percentage of CD4+ and CD8+ cells, and protein expression of galectin-1, respectively. The results of immunofluorescence assay (Fig. 5A) indicated that, compared with the control ${ }_{2}$ group, the expression level of desmin was found to be significantly elevated in the U0126 group, and the expression level of $\alpha$-SMA decreased evidently. The control ${ }_{2}$

Fig. 5. Observation of immune tolerance of liver transplantation, histopathological changes of liver lobule tissues, expression levels of IL- 2 , IL-10 and TGF- $\beta$, percentage of CD4+ and CD8+ cells, and protein expression of Galectin-1. Panel A, results of immunofluorescence assay showed that the MAPK/ERK inhibitor U0126 exerted protective effects on liver damage ( $\times 200$ ), scale $=50 \mu \mathrm{m}$; Panel B, U0126 reduced inflammatory responses and liver lesions by inhibiting the MAPK/ERK signaling pathway observed after HE staining $(\times 200)$, scale $=50 \mu \mathrm{m}$; Panel $\mathrm{C}$, MAPK/ ERK inhibitor U0126 inhibits inflammatory responses by ELISA; Panel D, the MAPK/ERK inhibitor U0126 increased the percentages

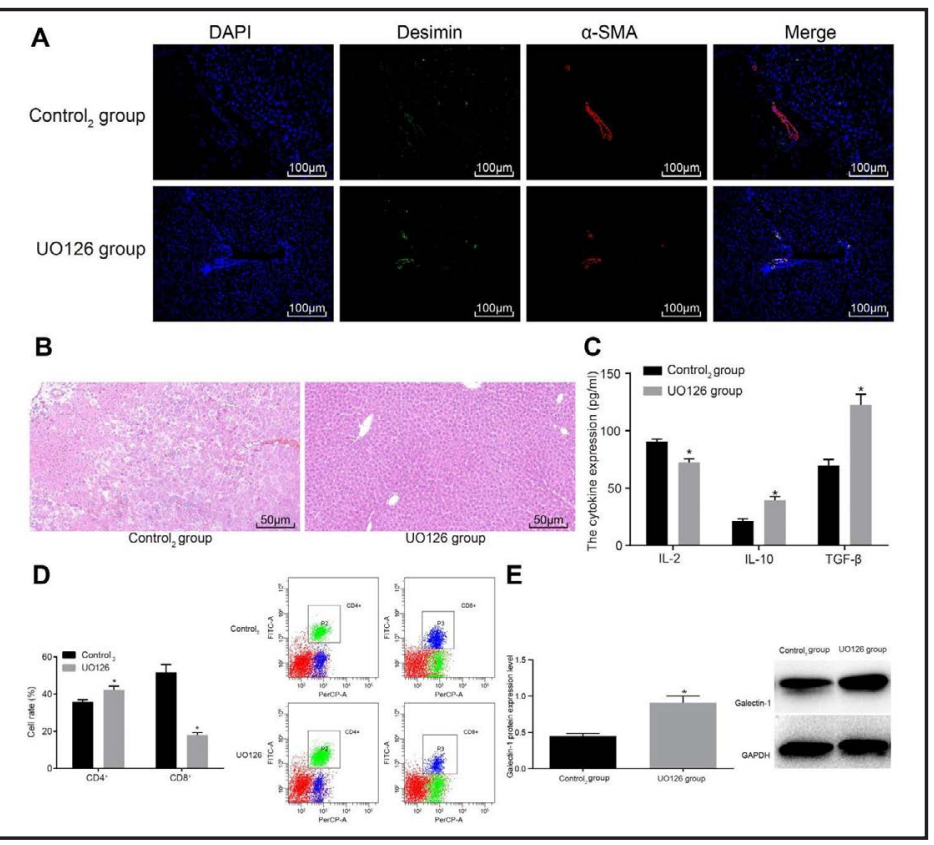
of $\mathrm{CD}^{+}$and $\mathrm{CD}^{+} \mathrm{T}$-cells and reduced the percentage of $\mathrm{CD} 8^{+} \mathrm{T}$-cells to promote immunosuppressive effect by flow cytometry; Panel E, U0126 increased the protein expression of Galectin-1 suggested by western blot

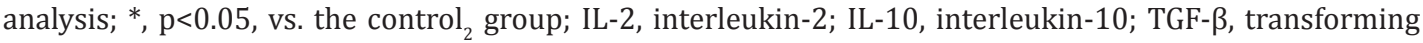
growth factor beta; DAPI, 4', 6-diamidino-2-phenylindole; $\alpha$-SMA, $\alpha$-smooth muscle actin; HE, hematoxylineosin; ELISA, enzyme-linked immunosorbent assay; GAPDH, glyceraldehyde-3-phosphate dehydrogenase. 
group was regarded as the mouse model of immune tolerance, and the most of the HSCs were found to be activated. After treatment with the MAPK/ERK inhibitor U0126, HSCs changed to the stationary state, indicating that the MAPK/ERK inhibitor U0126 exerted protective effects against liver damage.

The HE staining results (Fig. 5B) indicated that the control ${ }_{2}$ group exhibited unclear liver lobule structures, irregular cell arrangement, expanded sinus hepaticus to some extent, apparent inflammatory cell infiltration, and cell necrosis. The U0126 group showed clear liver lobule structures, regular cell arrangement, expanded sinus hepaticus to some extent, no obvious inflammatory cell infiltration and cell necrosis. The aforementioned findings indicated that U0126 could reduce inflammatory responses and liver lesions by inhibiting the MAPK/ERK signaling pathway.

The ELISA results (Fig. 5C) showed that, compared with the control ${ }_{2}$ group, the U0126 group exhibited decreased IL-2 levels and elevated levels of IL-10 and TGF- $\beta$ (all $p<0.05$ ), indicating that the MAPK/ERK inhibitor U0126 inhibited inflammatory responses.

Flow cytometric detection (Fig. 5D) revealed that, compared with the control $_{2}$ group, the percentages of $\mathrm{CD}^{+}$and $\mathrm{CD} 3^{+} \mathrm{T}$-cells were found to be obviously increased, whereas the percentage of $\mathrm{CD}^{+} \mathrm{T}$-cells evidently decreased in the U0126 group (all $p<0.05$ ). The results revealed that the MAPK/ERK inhibitor U0126 increased the percentages of $\mathrm{CD}^{+}$and $\mathrm{CD} 3^{+}$ $\mathrm{T}$-cells and reduced the percentage of $\mathrm{CD} 8^{+} \mathrm{T}$-cells to promote immunosuppressive effects, namely, inflammatory response inhibition.

The results of western blot analysis (Fig. 5E) showed that, compared with the control $_{2}$ group, the protein expression of galectin- 1 was found to be elevated in the U0126 group ( $p$ $<0.05$ ). The results suggested that U0126 increased the protein expression of galectin-1.

\section{Discussion}

The induction of specific immune tolerance has been reported to be a feasible approach to treating organ rejection [21]. Galalpha1-3Gal epitopes were expressed in pig tissues and the binding of anti-Galalpha1-3Gal led to endothelial cell activation and complement-mediated hyperacute graft rejection [22]. Recently, galectin-1 was demonstrated to significantly attenuate allogeneic immune responses in murine LT models [5]. In addition, galectin-1 has been noted to play a role in the mediation of immune tolerance in autoimmune and inflammatory settings [23]. Due to the lack of knowledge and research regarding galectin-1 and immune tolerance, the current study was performed aiming to investigate the effects of galectin-1 on immune tolerance in LT via the mediation of HSCs.

First, the results of the current study indicated that galectin-1 overexpression can enhance immune tolerance by inhibiting the proliferation of T-cells, decreasing IL-2 levels and increasing levels of IL-10 and TGF- $\beta$ in LT. Interestingly, IL-2, IL-10 and TGF- $\beta$ are cytokines regarded as key mediators in the induction and effector phases of all immune and inflammatory responses [24]. Previously, it was proved that IL-2 supports the proliferation of T-cells, suggesting that IL-2 levels are positively related to T-cell proliferation [25]. TGF- $\beta$ and IL-10 are known functional mediators of immunosuppression, and they exert great effects on controlling excessive immune responses [26]. In addition, it was reported that IL-10 and TGF- $\beta$ treatment inhibited the development of inflammatory responses [27]. Furthermore, a previous study strongly supported the hypothesis that galectin-1 participates in multiple biological processes in different tissues and cells, such as cell proliferation, apoptosis, and immunosuppression [28]. As an evolutionarily conserved glycan-binding protein, galectin-1 contributes to the creation of an immunosuppressed microenvironment at sites of tumor growth [29]. Moreover, galectin-1 was demonstrated to suppress cell viability and proliferation of nonmalignant T-cells in patients with leukemic cutaneous T-cell lymphoma [30]. There has been growing evidence showing that galectin-1 exerts anti-inflammatory effects in concanavalin A-induced hepatitis, and upregulation of galectin-1 in activated HSCs can modulate immune cell functioning [31,32]. The aforementioned evidence and findings 
suggested that galectin-1 inhibits $\mathrm{T}$ lymphocyte proliferation by regulating the levels of IL-2, IL-10 and TGF- $\beta$ to promote immune tolerance in LT. The Th1/Th2 balance exerts its function in transplantation immunology, and IL-2 and IL-10, two representative cytokines, play essential roles in regulating this balance [33]. In addition, highly upregulated galectin-1 in HSCs has been explored quite intensively in recent years, and the results have indicated that galectin-1 is generated by activated HSCs [34]. Furthermore, accumulating evidence has suggested that HSCs play an important role in liver transplant immune tolerance by inducing T lymphocyte apoptosis and regulating the expression of TGF- $\beta$ and IL-10 [3].

TGF- $\beta$, a polypeptide member of the transforming growth factor beta superfamily of cytokines, plays a pleiotropic role in acquired immunity and participates in T-cell regulation and regulatory responses. Interestingly, it has been reported that various immune cells and non-immune cells (peripheral lymphoid cells) can secrete TGF- $\beta$ or activate the TGF- $\beta /$ Smad pathway to inhibit T-cell proliferation [35]. The current study found that overexpression of galectin- 1 could induce TGF- $\beta 1$ secretion and inhibit the proliferation of T-cells, while silencing of galectin- 1 inhibited the secretion of TGF- $\beta 1$ and promoted the proliferation of T-cells, but the inhibition of proliferation could be reversed using a TGF- $\beta$ /Smad inhibitor. Simultaneously, it was also found that the addition of U0126, the MAPK/ERK pathway inhibitor in the U0126 group, significantly upregulated galectin-1 and increased TGF- $\beta 1$ secretion, and it enhanced the inhibition of proliferation of T-cells. In addition, a previous study revealed that the PI3K/AKT pathway inhibited the activation of NF- $\mathrm{KB}$ by activating AKT, mTOR and C/EBP $\beta$ to promote immunosuppression [36]. Thus, it can be suggested that the addition of the PI3K/AKT pathway can also rescue the inhibition of proliferation induced by overexpression of galectin-1. Additionally, the Rho/ROCK pathway, closely related to the TGF- $\beta$ pathway, has been demonstrated to activate the TGF- $\beta /$ Smad pathway and induce epithelial-mesenchymal transition (EMT) processes [37, 38]. Thereby, it can be concluded that the addition of Rho/ROCK pathway inhibitor also had the same rescue effect as the addition of TGF- $\beta$ /Smad inhibitor.

The overexpression of galectin-1 plays an immunosuppressive role and has been known to result in an increase in the percentage of CD4+/CD8. As previously mentioned, TGF- $\beta$ /Smad and PI3K/AKT pathways can mediate immunosuppression, which is trivial for maintaining homeostasis. Once the aforementioned pathways are abnormally blocked, it leads to an autoimmune reaction in vivo. In agreement with the aforementioned, the current study revealed that, compared with the Galectin- 1 OE group, the ratio of $\mathrm{CD} 4^{+} / \mathrm{CD}^{+}$in the Galectin-1 OE + pathway inhibitor group was found to be decreased, and the addition of these pathway inhibitors reversed the overexpression of galectin- 1 and increased the CD4+/ $\mathrm{CD}^{+}$ratio. Conversely, the MAPK/ERK pathway was found to promote the inflammatory response, and inhibition of the MAPK/ERK pathway resulted in an increased $C D 4^{+} / \mathrm{CD}^{+}$ratio. Furthermore, in follow-up experiments, repeated experiments in each group on the ratio of CD4+/CD8+ revealed that, on the $7^{\text {th }}$ day, the CD $4^{+} / \mathrm{CD}^{+}$ratio in the Galectin- 1 OE + U0126 group was significantly upregulated compared with the Galectin-1 OE group, and addition of U0126 could enhance the immunosuppression ability of galectin-1 overexpression.

In addition, the results of the current study revealed that high activation of HSCs was correlated with the enhancement of immune tolerance. HSCs, as unique nonparenchymal cells, play a potent immunoregulatory role in cotransplantation, with allogeneic islets effectively protecting the islet allografts from rejection, suggesting that HSCs possess immune regulatory effects [7]. Previously, it was indicated that allogeneic CD4+ T-cells, including Tregs, are closely related to HSCs [10]. Tregs play a significant role in inducing peripheral tolerance to self and foreign antigens [39]. As previously reported, the xenograft survival was longer in CD4+ T-cell-depleted mice, in contrast to in CD4+ T-cell mice [40]. In the current study, the results revealed increased expression of $\alpha$-SMA in $\mathrm{CCl}_{4}$-induced hepatic fibrosis; however, the expression of desmin was found to be decreased. It is known that intracellular desmin and $\alpha$ SMA have emerged as markers of quiescent and activated HSCs, respectively [41]. Additionally, $\alpha$-SMA overexpression has been reported to be correlated with increased liver fibrosis [42]. 
$\mathrm{CCl}_{4}$-induced hepatic fibrosis has been reported to be associated with apoptosis and proinflammatory cytokine genes, including TGF- $\beta$ [43]. Thus, the special effects of TGF- $\beta$ on hepatic fibrosis and immune tolerance might be an important research direction in achieving better prognoses in liver transplant recipients. In addition, liver function markers in serum comprised of Hyp ALT, AST, TBIL, and Hyp were used in our study in a bid to explore the effects of galectin-1 on immune tolerance and hepatic fibrosis in LT [44]. A previous study demonstrated that serum levels of ALT, AST, TBIL, and Hyp were found to be significantly elevated in liver tissues in mouse models of liver fibrosis [45]. The current study also revealed that the activation might be a contributor to immune tolerance enhancement. In addition, various studies have indicated that induced HSCs resulted in increased extracellular matrix production and collagen degradation during the progression of liver fibrosis, and they are considered to be the major producers of fibrotic nonmatrix in liver injury [46-48].

In conclusion, the current study demonstrated that overexpression of galectin-1 inhibited the proliferation of T-cells by means of HSC activation, which reduced the inflammatory response by exerting immunosuppressive effects and furthermore enhanced immune tolerance and alleviated hepatic fibrosis in LT. The findings of the current study might provide a new therapeutic target for immunological rejection after LT. However, further studies are warranted to explore the underlying mechanism in the future, based on larger sample sizes.

\section{Acknowledgements}

This study was supported by the National Natural Science Foundation of China (Grant No. 81471581), the Project of Rising Star of Health Bureau of Zhejiang Province and Research on Public Welfare Technology and the Social Development Project of Zhejiang Provincial Bureau of Science and Technology (Grant No. 2015C33151). We would like to acknowledge the reviewers for their helpful comments on this paper.

\section{Disclosure Statement}

The authors declare that they have no competing interests.

\section{References}

1 Otto G: Liver transplantation: an appraisal of the present situation. Dig Dis 2013;31:164-169.

2 Gassa A, Kalkavan H, Jian F, Duhan V, Khairnar V, Shaabani N, Honke N, Carpinteiro A, Botezatu L, Crivello P, Dolff S, Ferencik S, Haussinger D, Khandanpour C, Fleischhauer K, Witzke O, Wahlers T, Hardt C, Lang PA, Lang KS: High Frequencies of Anti-Host Reactive CD8+ T Cells Ignore Non-Hematopoietic Antigen after Bone Marrow Transplantation in a Murine Model. Cell Physiol Biochem 2016;38:1343-1353.

3 Jiang Z, Chen Y, Feng X, Jiang J, Chen T, Xie H, Zhou L, Zheng S: Hepatic stellate cells promote immunotolerance following orthotopic liver transplantation in rats via induction of $\mathrm{T}$ cell apoptosis and regulation of Th2/Th3-like cell cytokine production. Exp Ther Med 2013;5:165-169.

-4 Ye Y, Yan S, Jiang G, Zhou L, Xie H, Xie X, Yu X, Ding Y, Tian J, Dai Y, Zheng S: Galectin-1 prolongs survival of mouse liver allografts from Flt3L-pretreated donors. Am J Transplant 2013;13:569-579.

5 Wang Y, Tian Y, Ding Y, Wang J, Yan S, Zhou L, Xie H, Chen H, Li H, Zhang J, Zhao J, Zheng S: MiR-152 may silence translation of CaMK II and induce spontaneous immune tolerance in mouse liver transplantation. PLoS One 2014;9:e105096.

6 Tiegs G, Lohse AW: Immune tolerance: what is unique about the liver. J Autoimmun 2010;34:1-6.

7 Hsieh CC, Hung CH, Lu L, Qian S: Hepatic immune tolerance induced by hepatic stellate cells. World J Gastroenterol 2015;21:11887-11892. 


\section{Cellular Physiology Cell Physiol Biochem 2018;48:863-879 \begin{tabular}{ll|l} 
DOI: 10.1159/000491955 & O 2018 The Author(s). Published by S. Karger AG, Basel \\
www.karger.com/cpb
\end{tabular}

8 Banh A, Zhang J, Cao H, Bouley DM, Kwok S, Kong C, Giaccia AJ, Koong AC, Le QT: Tumor galectin-1 mediates tumor growth and metastasis through regulation of T-cell apoptosis. Cancer Res 2011;71:4423-4431.

-9 Sasaguri K, Yamada K, Narimatsu Y, Oonuki M, Oishi A, Koda K, Kubo KY, Yamamoto T, Kadoya T: Stress-induced galectin-1 influences immune tolerance in the spleen and thymus by modulating CD45 immunoreactive lymphocytes. J Physiol Sci 2017;67:489-496.

10 Dangi A, Sumpter TL, Kimura S, Stolz DB, Murase N, Raimondi G, Vodovotz Y, Huang C, Thomson AW, Gandhi CR: Selective expansion of allogeneic regulatory T cells by hepatic stellate cells: role of endotoxin and implications for allograft tolerance. J Immunol 2012;188:3667-3677.

11 Sato H, Ozawa K, Iwata S, Kaihara S, Ogura Y, Fujimoto Y, Ono M, Hodohara K, Uemoto S, Nakamura H, Takai K, Tanaka K: Role of bcl-2 mRNA in homeostatic proliferation in circulating T-cells in human liver transplant patients after T-cell depletion. J Surg Res 2005;127:123-130.

$\checkmark 12$ Iwamoto M, Taguchi C, Sasaguri K, Kubo KY, Horie H, Yamamoto T, Onozuka M, Sato S, Kadoya T: The Galectin-1 level in serum as a novel marker for stress. Glycoconj J 2010;27:419-425.

13 Than NG, Romero R, Erez O, Weckle A, Tarca AL, Hotra J, Abbas A, Han YM, Kim SS, Kusanovic JP, Gotsch F, Hou Z, Santolaya-Forgas J, Benirschke K, Papp Z, Grossman LI, Goodman M, Wildman DE: Emergence of hormonal and redox regulation of galectin-1 in placental mammals: implication in maternal-fetal immune tolerance. Proc Natl Acad Sci U S A 2008;105:15819-15824.

14 You Y, Tan JX, Dai HS, Chen HW, Xu XJ, Yang AG, Zhang YJ, Bai LH, Bie P: MiRNA-22 inhibits oncogene galectin-1 in hepatocellular carcinoma. Oncotarget 2016;7:57099-57116.

15 Ichikawa S, Mucida D, Tyznik AJ, Kronenberg M, Cheroutre H: Hepatic stellate cells function as regulatory bystanders. J Immunol 2011;186:5549-5555.

16 Winau F, Hegasy G, Weiskirchen R, Weber S, Cassan C, Sieling PA, Modlin RL, Liblau RS, Gressner AM, Kaufmann SH: Ito cells are liver-resident antigen-presenting cells for activating $\mathrm{T}$ cell responses. Immunity 2007;26:117-129.

17 Chen CH, Shu KH, Su YH, Tang KY, Cheng CH, Wu MJ, Yu TM, Chuang YW, Hu C: Cotransplantation of hepatic stellate cells attenuates the severity of graft-versus-host disease. Transplant Proc 2010;42:971-975.

18 Charles R, Chou HS, Wang L, Fung JJ, Lu L, Qian S: Human hepatic stellate cells inhibit T-cell response through B7-H1 pathway. Transplantation 2013;96:17-24.

19 Esser JS, Saretzki E, Pankratz F, Engert B, Grundmann S, Bode C, Moser M, Zhou Q: Bone morphogenetic protein 4 regulates microRNAs miR-494 and miR-126-5p in control of endothelial cell function in angiogenesis. Thromb Haemost 2017;117:734-749.

20 Wang X, Sun L, Wang X, Kang H, Ma X, Wang M, Lin S, Liu M, Dai C, Dai Z: Acidified bile acids enhance tumor progression and telomerase activity of gastric cancer in mice dependent on c-Myc expression. Cancer Med 2017;6:788-797.

21 Xie J, Wang Y, Bao J, Ma Y, Zou Z, Tang Z, Dong R, Wen H: Immune tolerance induced by RelB short-hairpin RNA interference dendritic cells in liver transplantation. J Surg Res 2013;180:169-175.

22 Ramos A, Ruiz JC, de Francisco AL, Gomez-Fleitas M, Arias M: Removal of xenoreactive antibodies by protein-A immunoadsorption: experience in 22 patients. Xenotransplantation 2000;7:14-20.

23 Salatino M, Croci DO, Bianco GA, Ilarregui JM, Toscano MA, Rabinovich GA: Galectin-1 as a potential therapeutic target in autoimmune disorders and cancer. Expert Opin Biol Ther 2008;8:45-57.

-24 Chen Z, Bouamar R, Van Schaik RH, De Fijter JW, Hartmann A, Zeier M, Budde K, Kuypers DR, Weimar W, Hesselink DA, Van Gelder T: Genetic polymorphisms in IL-2, IL-10, TGF-beta1, and IL-2RB and acute rejection in renal transplant patients. Clin Transplant 2014;28:649-655.

25 Endharti AT, Zhou YW, Nakashima I, Suzuki H: Galectin-1 supports survival of naive T cells without promoting cell proliferation. Eur J Immunol 2005;35:86-97.

-26 Scholzen A, Mittag D, Rogerson SJ, Cooke BM, Plebanski M: Plasmodium falciparum-mediated induction of human CD25Foxp3 CD4 T cells is independent of direct TCR stimulation and requires IL-2, IL-10 and TGFbeta. PLoS Pathog 2009;5:e1000543.

27 Li W, Liu T, Wu L, Chen C, Jia Z, Bai X, Ruan D: Blocking the function of inflammatory cytokines and mediators by using IL-10 and TGF-beta: a potential biological immunotherapy for intervertebral disc degeneration in a beagle model. Int J Mol Sci 2014;15:17270-17283.

-28 Geiger P, Mayer B, Wiest I, Schulze S, Jeschke U, Weissenbacher T: Binding of galectin-1 to breast cancer cells MCF7 induces apoptosis and inhibition of proliferation in vitro in a 2D- and 3D- cell culture model. BMC Cancer 2016;16:870. 


\section{Cellular Physiology Cell Physiol Biochem 2018;48:863-879 \begin{tabular}{l|l} 
DOI: 10.1159/000491955 & $\begin{array}{l}\text { O } 2018 \text { The Author(s). Published by S. Karger AG, Basel } \\
\text { www.karger.com/cpb }\end{array}$
\end{tabular}

29 Dalotto-Moreno T, Croci DO, Cerliani JP, Martinez-Allo VC, Dergan-Dylon S, Mendez-Huergo SP, Stupirski JC, Mazal D, Osinaga E, Toscano MA, Sundblad V, Rabinovich GA, Salatino M: Targeting galectin-1 overcomes breast cancer-associated immunosuppression and prevents metastatic disease. Cancer Res 2013;73:11071117.

-30 Cedeno-Laurent F, Watanabe R, Teague JE, Kupper TS, Clark RA, Dimitroff CJ: Galectin-1 inhibits the viability, proliferation, and Th1 cytokine production of nonmalignant $\mathrm{T}$ cells in patients with leukemic cutaneous T-cell lymphoma. Blood 2012;119:3534-3538.

-31 Than NG, Kim SS, Abbas A, Han YM, Hotra J, Tarca AL, Erez O, Wildman DE, Kusanovic JP, Pineles B, Montenegro D, Edwin SS, Mazaki-Tovi S, Gotsch F, Espinoza J, Hassan SS, Papp Z, Romero R: Chorioamnionitis and increased galectin-1 expression in PPROM --an anti-inflammatory response in the fetal membranes? Am J Reprod Immunol 2008;60:298-311.

32 Tang D, Yuan Z, Xue X, Lu Z, Zhang Y, Wang H, Chen M, An Y, Wei J, Zhu Y, Miao Y, Jiang K: High expression of Galectin-1 in pancreatic stellate cells plays a role in the development and maintenance of an immunosuppressive microenvironment in pancreatic cancer. Int J Cancer 2012;130:2337-2348.

33 Xu X, Gao X, Zhao X, Liao Y, Ji W, Li Q, Li J: PU.1-Silenced Dendritic Cells Induce Mixed Chimerism and Alleviate Intestinal Transplant Rejection in Rats via a Th1 to Th2 Shift. Cell Physiol Biochem 2016;38:220228.

34 Maeda N, Kawada N, Seki S, Arakawa T, Ikeda K, Iwao H, Okuyama H, Hirabayashi J, Kasai K, Yoshizato K: Stimulation of proliferation of rat hepatic stellate cells by galectin- 1 and galectin-3 through different intracellular signaling pathways. J Biol Chem 2003;278:18938-18944.

-35 Travis MA, Sheppard D: TGF-beta activation and function in immunity. Annu Rev Immunol 2014;32:51-82.

-36 Kaneda MM, Messer KS, Ralainirina N, Li H, Leem CJ, Gorjestani S, Woo G, Nguyen AV, Figueiredo CC, Foubert P, Schmid MC, Pink M, Winkler DG, Rausch M, Palombella VJ, Kutok J, McGovern K, Frazer KA, Wu X, Karin M, Sasik R, Cohen EE, Varner JA: PI3Kgamma is a molecular switch that controls immune suppression. Nature 2016;539:437-442.

-37 Korol A, Taiyab A, West-Mays JA: RhoA/ROCK signaling regulates TGFbeta-induced epithelial-mesenchymal transition of lens epithelial cells through MRTF-A. Mol Med 2016;22:

-38 Feng ZH, Zhang XH, Zhao JQ, Ma JZ: Involvement of Rho-associated coiled-coil kinase signaling inhibition in TGF-beta1/Smad2, 3 signal transduction in vitro. Int J Ophthalmol 2017;10:1805-1811.

39 Wan J, Huang F, Hao S, Hu W, Liu C, Zhang W, Deng X, Chen L, Ma L, Tao R: Interleukin-10 Gene-Modified Dendritic Cell-Induced Type 1 Regulatory T Cells Induce Transplant-Tolerance and Impede Graft Versus Host Disease After Allogeneic Stem Cell Transplantation. Cell Physiol Biochem 2017;43:353-366.

40 Dong Z, Chen Y, Peng Y, Wang F, Yang Z, Huang G, Chen Y, Yuan Z, Cao T, Peng Y: Concurrent CCR7 Overexpression and RelB Knockdown in Immature Dendritic Cells Induces Immune Tolerance and Improves Skin-Graft Survival in a Murine Model. Cell Physiol Biochem 2017;42:455-468.

-41 Takenouchi T, Yoshioka M, Yamanaka N, Kitani H: Reversible conversion of epithelial and mesenchymal phenotypes in SV40 large T antigen-immortalized rat liver cell lines. Cell Biol Int Rep (2010) 2010;17:e00001.

42 Dong R, Luo Y, Zheng S: alpha-SMA overexpression associated with increased liver fibrosis in infants with biliary atresia. J Pediatr Gastroenterol Nutr 2012;55:653-656.

43 Wang T, Zhao LJ, Li P, Jiang H, Lu GC, Zhang WD, Li HL, Yuan BJ: Hepatoprotective effects and mechanisms of dehydrocavidine in rats with carbon tetrachloride-induced hepatic fibrosis. J Ethnopharmacol 2011;138:76-84.

44 Tang N, Zhang Y, Liu Z, Fu T, Liang Q, Ai X: Correlation analysis between four serum biomarkers of liver fibrosis and liver function in infants with cholestasis. Biomed Rep 2016;5:107-112.

45 Zhao Z, Yu H, Peng Y, Ren H, Tao Y, Wang Z, Zhu B, Liu P, Liu C: [Comparison of effect of formulas clearing away heat and promoting blood circulation on prevention and treatment of liver fibrosis in CCl4 mice]. Zhongguo Zhong Yao Za Zhi 2012;37:1804-1808.

46 Du SL, Wang JY, Pan H, Lu WY, Wang J: [Antifibrotic effects of cyclic RGD-peptide mediated liposomal interferon: an experimental on rats]. Zhonghua Yi Xue Za Zhi 2005;85:1015-1020.

47 Gaca MD, Zhou X, Issa R, Kiriella K, Iredale JP, Benyon RC: Basement membrane-like matrix inhibits proliferation and collagen synthesis by activated rat hepatic stellate cells: evidence for matrix-dependent deactivation of stellate cells. Matrix Biol 2003;22:229-239.

-48 Puche JE, Saiman Y, Friedman SL: Hepatic stellate cells and liver fibrosis. Compr Physiol 2013;3:1473-1492. 